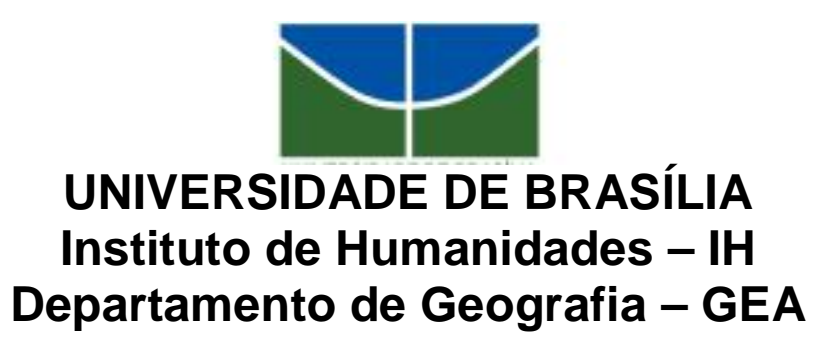

CAMILA ALMEIDA

\title{
EDUCAÇÃO AMBIENTAL E UNIDADES DE CONSERVAÇÃO: A INCLUSÃO DA POPULAÇAO COMO ALTERNATIVA DE MANEJO DO PARQUE NACIONAL DE BRASÍLIA
}




\section{UNIVERSIDADE DE BRASÍLIA Instituto de Humanidades - IH Departamento de Geografia - GEA}

CAMILA ALMEIDA

\section{EDUCAÇÃO AMBIENTAL E UNIDADES DE CONSERVAÇÃO: A INCLUSÃO DA POPULAÇAO COMO ALTERNATIVA DE MANEJO DO PARQUE NACIONAL DE BRASÍLIA}

Monografia apresentada à Banca Examinadora do Departamento de Geografia da Universidade de Brasília como exigência final para obtenção do título de Bacharel em Geografia. Sob a orientação do Prof. Msc Juvair Fernandes de Freitas. 


\title{
EDUCAÇÃO AMBIENTAL E UNIDADES DE CONSERVAÇÃO: A INCLUSÃO DA POPULAÇAO COMO ALTERNATIVA DE MANEJO DO PARQUE NACIONAL DE BRASÍLIA
}

\author{
Monografia apresentada à Banca \\ Examinadora do Departamento de \\ Geografia da Universidade de Brasília \\ como exigência final para obtenção do \\ título de Bacharel em Geografia.
}

Aprovada em $/ 2009$

BANCA EXAMINADORA

Prof MSc. Juvair Fernandes de Freitas

(Orientador)

Prof Dr. Dante Flávio da Costa Reis Júnior

(Examinador)

Prof Dr. Valdir Adilson Steinke

(Examinador) 
Dedico este trabalho a todos os familiares e amigos que me auxiliaram nessa jornada.

Aos meus pais e a minha irmã que sempre me apoiaram durante estes anos.

E aos meus amigos de universidade que tornaram esta fase da minha vida ainda mais especial.

iii 


\section{AGRADECIMENTOS}

Agradeço a Deus, por ter me dado saúde e condições para chegar até aqui. Aos meus familiares e amigos, pelo apoio e pela compreensão nos momentos em que a dedicação aos estudos foi exclusiva.

Aos meus pais que sempre me aconselharam e estiveram dispostos a me ajudar sempre que surgia alguma dificuldade.

Aos meus professores, pela dedicação, paciência e ensinamentos disponibilizados nas aulas, que contribuíram para a minha formação e para a realização desse trabalho; principalmente ao meu orientador neste trabalho professor Juvair Fernandes de Freitas, pela dedicação e ensinamentos dispensados para a conclusão dessa monografia.

A todos que contribuíram direta ou indiretamente para a realização deste trabalho meu eterno agradecimento. 


\section{Resumo}

Localizado próximo a uma área urbana, o Parque Nacional de Brasília sofre pressões antrópicas que aumentam gradativamente junto com a expansão urbana. Além da ocupação desordenada do seu entorno, um dos grandes problemas enfrentados pelo parque são os comportamentos e os impactos das ações da população sobre a área. É de grande importância a Educação Ambiental dos freqüentadores do Parque, despertando neles o interesse pela área, a fim de incluindo-os no processo de preservação e conscientização ambiental, como forma de auxiliar no manejo desta Unidade de Conservação.

Palavras Chave: Educação Ambiental, Meio Ambiente, Parque Nacional de Brasília. 


\section{SUMÁRIO:}

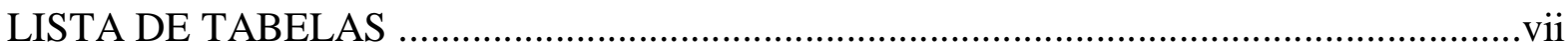

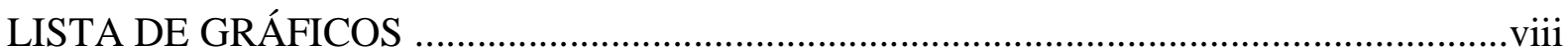

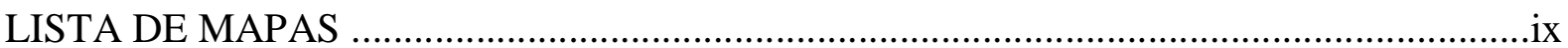

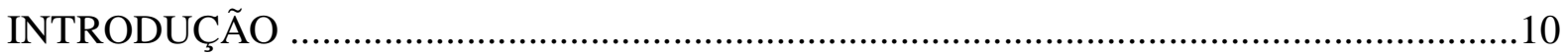

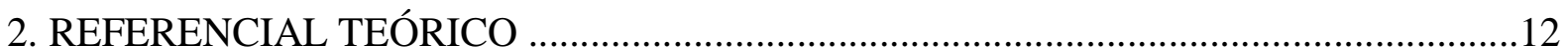

2.1. Conceito de Educação Ambiental ........................................................................12

2.2. Conceituação de Meio Ambiente .............................................................................14

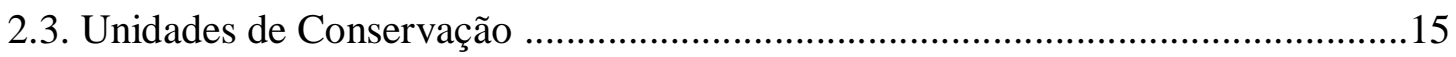

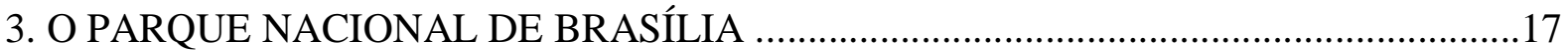

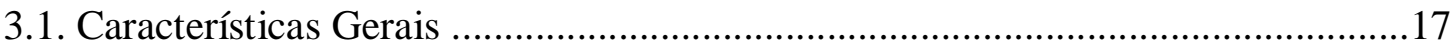

3.2. Histórico do Parque ……….................................................................................19

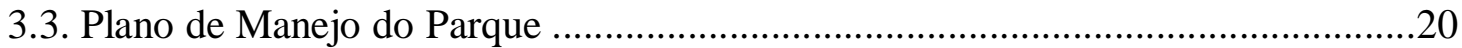

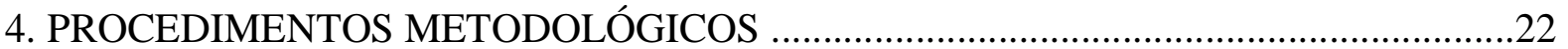

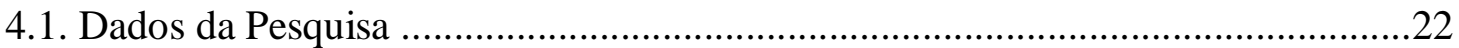

4.2. Análise e Discussão dos Dados ............................................................................22

5. PROGRAMAS DE EDUCAÇÃO AMBIENTAL E INCLUSÃO DA POPULAÇÃO NO

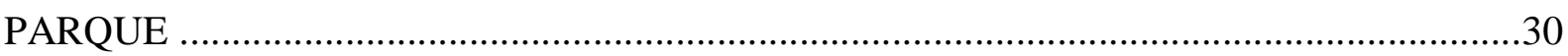

6. A INCLUSÃO DA POPULAÇÃO COMO ALTERNATIVA NO MANEJO DA ÁREA....32

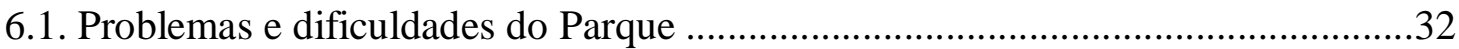

6.2. Resultados alcançados e soluções possíveis com o apoio da população ................34

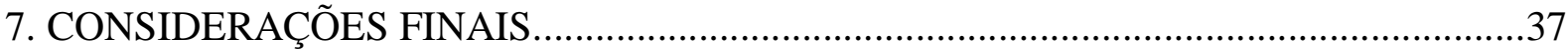

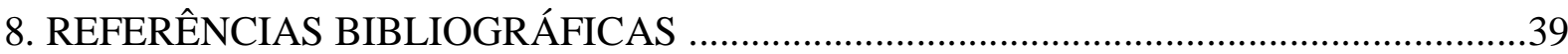

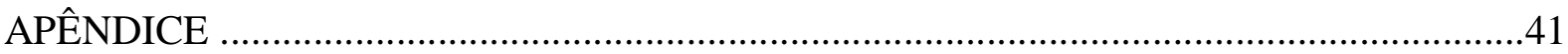




\section{LISTA DE TABELAS:}

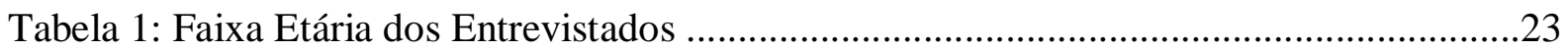

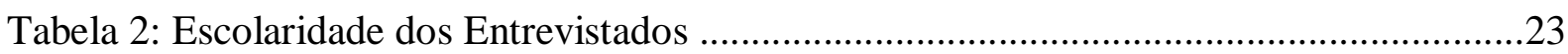

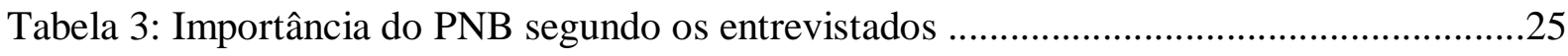

Tabela 4: Problemas enfrentados pelo PNB segundo os entrevistados .................................26

Tabela 5: Formas de contribuir com o PNB segundo os entrevistados..................................29

Tabela 6: Visitantes Espontâneos (Brasil) que frequentaram o Centro de Visitantes e

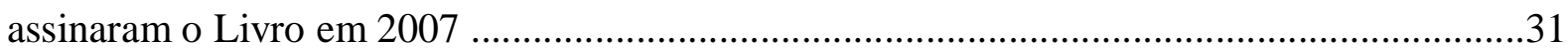

Tabela 7: Visitantes Espontâneos de outras nações que frequentaram o Centro de Visitantes e

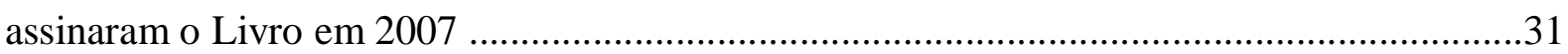




\section{LISTA DE GRÁFICOS:}

Gráfico 1: Percentual da frequência dos visitantes do PNB .24

Gráfico 2: Percentual de entrevistados que leram ou ouviram alguma noticia sobre o PNB...25

Gráfico 3: Percentual de Interessados em auxiliar na preservação do PNB .28

viii 


\section{LISTA DE MAPAS:}

Mapa 1: Parque Nacional de Brasília - Localização 


\section{Introdução}

O Parque Nacional de Brasília situa-se próximo a uma área urbana e sofre pressão por este motivo. Invasões, especulação imobiliária, acúmulo de lixo em seus limites, queimadas são alguns dos problemas enfrentados. Além das pressões externas, o parque também sofre com algumas ações praticadas por seus visitantes, que utilizam o parque apenas como uma forma de lazer, desconhecendo a sua real importância, por na maioria das vezes não receberem nenhuma orientação sobre a melhor forma de utilizar a área sem causar tantos impactos negativos.

É necessário que os usuários do Parque Nacional conheçam a sua importância. Esse conhecimento se dá principalmente pela Educação Ambiental, prática que envolve a compreensão do meio ambiente e de suas relações, despertando o interesse e incentivando a participação social na preservação como exercício da cidadania, integrando as metas de manejo com os aspectos sociais a fim de minimizar os problemas causados pela visitação e de conscientizar a população da importância dessa Unidade.

Grande parte dos frequentadores do Parque desconhecem o fato de estarem em uma Unidade de Conservação, o que pode justificar algumas atitudes negativas que eles exercem sobre a área. Com a conscientização dessa parcela da população, é possível atingir relevantes melhorias no manejo do Parque, fazendo que cada um torne-se um fiscal de si mesmo quanto ao que faz dentro da unidade e que consequências isso pode causar.

O objetivo geral deste trabalho é mostrar como a Educação Ambiental pode ocasionar uma inclusão dos freqüentadores do Parque no processo de preservação, auxiliando no manejo e causando interferências positivas nessa Unidade de Conservação. Para isso torna-se necessário conhecer o plano de manejo do Parque, bem como os projetos que incluem a participação da população no processo de preservação, e analisar a visão dos frequentadores quanto ao parque, verificando se eles realmente conhecem a importância ambiental da Unidade de Conservação e as interferências que eles podem causar na área.

A realização de pesquisas sobre o tema é relevante na medida em que oferece contribuições importantes para a análise das relações entre a população e as Unidades de Conservação. Através da pesquisa realizada neste trabalho é possível notar qual a real importância que a população do Distrito Federal associa ao Parque Nacional de Brasília, 
analisando os principais aspectos citados nas respostas obtidas nas entrevistas realizadas. É importante também, notar o interesse (ou desinteresse) da população em ajudar na preservação da área, aspecto abordado na pesquisa e que mostra a relação entre o conhecimento das funções do Parque Nacional e a disposição em ajudar de alguma forma no manejo da área.

A pesquisa realizada ainda demonstra como a Educação Ambiental dentro do Parque precisa ser mais abrangente, a fim de atingir o público visitante e inclúi-los na preservação do Parque como forma de manejo da área, e não como mais uma fonte de problemas ambientais a serem solucionados. 


\section{Referencial Teórico}

\subsection{O Conceito de Educação Ambiental}

As atividades humanas são as maiores influenciadoras do ambiente. Todas as decisões, políticas, sociais e econômicas causam algum impacto maior ou menor, no seu meio. Cabe a Educação Ambiental propor mudanças no relacionamento entre o ser humano e o ambiente, ampliando a percepção de como interferem, interagem e são afetados pelo mesmo.

Em 1996, o CONAMA - Conselho Nacional do Meio Ambiente, definiu a Educação Ambiental como "um processo de formação e informação, orientado para o desenvolvimento da consciência crítica sobre as questões ambientais e de atividades que levem à participação das comunidades na preservação do equilíbrio ambiental" (aput DIAS, 2004, p.15). A educação ambiental trata, portanto, não apenas do processo de transmissão de informação, mas sim em estimular a cidadania, através da participação social na preservação.

Para DIAS, a Educação Ambiental "deve permitir a compreensão da natureza complexa do meio ambiente e interpretar a interdependência entre os diversos elementos que conformam o ambiente, com vistas a utilizar racionalmente os recursos do meio" (DIAS, 2004, p.16). Segundo esse autor, a Educação Ambiental deve capacitar ao exercício da cidadania através de uma base de conceitos abrangente e apta para permitir a utilização sustentada do meio. Além do conceito de preservação, visto na definição do CONAMA, esse autor trás o uso racional dos recursos como uma das metas da Educação Ambiental.

O Brasil possui hoje uma política específica para a Educação Ambiental, a Política Nacional de Educação Ambiental (PNEA), crida pela Lei n. 9795 de 27 de abril de 1999. O Artigo $1^{\circ}$ desta lei traz como conceito de Educação: "Os processos por meio dos quais o indivíduo e a coletividade constroem valores sociais, conhecimentos, habilidades, atitudes e competências voltadas para a conservação do meio ambiente, bem de uso comum do povo, essencial à sadia qualidade de vida e sua sustentabilidade" (BRASIL, 1999). A PNEA trouxe o apoio legal a Educação Ambiental, transformando-a em um "componente essencial e permanente da educação nacional" (BRASIL, 1999) e delegando responsabilidades as diversas esferas públicas e privadas, no processo educativo-ambiental.

O Artigo $5^{\circ}$ desta lei trás os objetivos fundamentais da Educação Ambiental: 
Art. $5^{\circ}$ São objetivos fundamentais da educação ambiental:

I - o desenvolvimento de uma compreensão integrada do meio ambiente em suas múltiplas e complexas relações, envolvendo aspectos ecológicos, psicológicos, legais, políticos, sociais, econômicos, científicos, culturais e éticos;

II - a garantia de democratização das informações ambientais;

III - o estímulo e o fortalecimento de uma consciência crítica sobre a problemática ambiental e social;

IV - o incentivo à participação individual e coletiva, permanente e responsável, na preservação do equilíbrio do meio ambiente, entendendo-se a defesa da qualidade ambiental como um valor inseparável do exercício da cidadania;

V - o estimulo à cooperação entre as diversas regiões do País, em níveis micro e macrorregionais, com vistas à construção de uma sociedade ambientalmente equilibrada, fundada nos princípios da liberdade, igualdade, solidariedade, democracia, justiça social, responsabilidade e sustentabilidade;

VI - o fomento e o fortalecimento da integração com a ciência e tecnologia;

VII - o fortalecimento da cidadania, autodeterminação dos povos e solidariedade como fundamentos para o futuro da humanidade. (BRASIL, 1999)

A Educação Ambiental envolve a compreensão do meio ambiente e de suas relações, e deve incentivar a participação social na preservação como exercício da cidadania, integrando as metas de manejo com os aspectos sociais. Pode-se dizer que a educação Ambiental é um processo permanente no qual o indivíduo e a comunidade tomam consciência do seu meio ambiente e adquirem conhecimentos, valores, habilidades, experiências e determinação, que os tornem aptos a agir e resolver problemas ambientais.

Pode-se dividir a Educação Ambiental em três categorias: A Educação Ambiental Formal, a Informal e a Não-formal. A Educação Ambiental formal é a desenvolvida no âmbito dos currículos das instituições de ensino públicas ou privadas, como prática de ensino integrada e permanente (Lei 9795/99 - art.9). A Educação Ambiental Informal, segundo alguns educadores, é a transmitida informalmente por alguns meios de comunicação, sendo em filmes, notícias, propagandas, etc., sendo necessária a avaliação dos conceitos passados, que podem ser muitas vezes voltados a interesses parciais. Já a Educação Ambiental Nãoformal é a que daremos maior ênfase neste estudo, sendo aquela que se constitui de ações e práticas educativas a fim de sensibilizar a população sobre as questões ambientais e de organizá-la para participar na defesa da qualidade do meio ambiente. Dentro desta definição, cabe o trabalho de instituições ambientalistas, sindicatos, empresas privadas, associações de moradores ou, como no caso do Parque Nacional de Brasília, uma proposta educativa para visitantes e moradores do entorno de uma área de preservação. 


\subsection{Conceituação de Meio Ambiente}

Segundo TROPPMAIR (2004, p.5), pode-se definir o Meio Ambiente como sendo "o complexo de elementos e fatores físicos, químicos, biológicos e sociais que interagem entre si com reflexos recíprocos afetando, de forma direta e muitas vezes visível, os seres vivos”. Em outras palavras, pode-se dizer que o Meio Ambiente é formado pelos fatores abióticos, bióticos e a cultura humana (seus paradigmas e valores), sempre em interação.

No início, o conceito de Meio Ambiente considerava apenas os aspectos físicos, químicos e biológicos, excluindo o ser humano como ser social. Com o passar dos anos, esse conceito evoluiu, e uma concepção mais ampla de Meio Ambiente incluía também os aspectos sociais, econômicos, políticos e culturais correlacionados com os fatores físicos. Segundo MEDINA (1994), o meio ambiente é um produto gerado ao longo do tempo, resultado do processo histórico-cultural de transformação do espaço pela sociedade. Sendo o ser humano o agente modificador do meio, os problemas ambientais devem ser analisados sobre a ótica das relações entre o meio natural e os fatores culturais.

REIGOTA (1991, p. 37) define o Meio Ambiente "como o lugar determinado ou percebido onde os elementos naturais e sociais estão em relações dinâmicas e em interação. Essas relações implicam processos de criação cultural e tecnológica e processos históricos e sociais de transformação do meio natural e construído". Para o autor, o Meio Ambiente é percebido quando cada indivíduo o limita de acordo com o seu conhecimento e suas representações sociais. As relações e interações indicam que ele encontra-se em constante mudança, resultante da dialética homem e meio; transformando o meio, o homem também é transformado por ele.

Para SANTOS (2006) não existe Meio Ambiente diferente do meio. Os agravos ao Meio Ambiente são agravos ao meio de vida do ser humano. Para o autor, usar esse conceito pode parecer reducionismo, dando a impressão de se levar em consideração apenas os aspectos ecológicos em questão, deixando de lado os problemas sociais. "Essas reduções, no caso da questão do meio ambiente, renovam o perigo já enunciado de sermos levados a elaborar uma cadeia causal que, no caso do planejamento tópico, pode levar ao absurdo de fazer com que, na produção do conhecimento, o efeito apareça precedendo a causa” (SANTOS, 2006, sem página). 


\subsection{Unidades de Conservação}

De acordo com o Sistema Nacional de Unidades de Conservação - SNUC, Unidade de Conservação (2000) pode ser definida como um "espaço territorial e seus recursos ambientais, incluindo as águas jurisdicionais, com características naturais relevantes, legalmente instituído pelo Poder Público, com objetivos de conservação e limites definidos, sob regime especial de administração, ao qual se aplicam garantias adequadas de proteção”.

O SNUC divide as unidades de conservação em Unidades de Proteção Integral e Unidades de Uso Sustentável, sendo na primeira admitido o uso apenas indireto dos seus recursos naturais, salvo casos previstos na lei; e a última com o objetivo de compatibilizar a conservação com o uso sustentável. Entre as Unidades de Proteção Integral temos:

B Estação Ecológica: tem como objetivo a preservação da natureza e a realização de pesquisas científicas, de domínio público, a visitação só é permitida com fins educacionais e a pesquisa científica necessita de permissão prévia do órgão responsável.

ß Reserva Biológica: tem como objetivo a preservação integral da biota e demais atributos naturais, sendo permitidas apenas as alterações que visem recuperar ecossistemas alterados e as ações de manejo necessárias. Quanto à visitação e pesquisa, aplicam-se as mesmas normas da Estação ecológica.

B Parque Nacional: "tem como objetivo básico a preservação de ecossistemas naturais de grande relevância ecológica e beleza cênica, possibilitando a realização de pesquisas científicas e o desenvolvimento de atividades de educação e interpretação ambiental, de recreação em contato com a natureza e de turismo ecológico" (BRASIL, 2000, Art.11). A categoria pode ser criada também pelo Estado ou Município, sendo denominadas Parque Estadual ou Parque Natural Municipal. A visitação pública fica sujeita as normas estabelecidas no Plano de Manejo da Unidade.

B Monumento Natural: com o objetivo de preservar sítios naturais raros, de grande beleza cênica ou singulares. Pode ser constituído de áreas particulares, ou em caso de desconformidade com os objetivos, a área pode ser desapropriada. A visitação, assim como nos Parques nacionais, também fica a critério do Plano de Manejo. 
B Refúgio da Vida Silvestre: protege ambientes naturais onde se asseguram as condições de existência e reprodução de espécies residentes ou migratórias. As normas e restrições são as mesmas do Monumento Natural.

Na categoria de Uso Sustentável, encontram-se:

B Área de Proteção Ambiental: área extensa, com certo grau de ocupação humana, porém importante para a qualidade de vida e bem-estar das populações humanas. Tem como objetivo proteger a diversidade biológica, assegurar o uso sustentável dos recursos naturais e controlar o processo de ocupação. Pode ser constituída por terras públicas ou privadas.

B Área de Relevante Interesse Ecológico: terras públicas ou privadas, de pequena extensão, com pouca ou nenhuma ocupação humana, mas que abriga exemplares raros da biota regional ou apresenta características naturais extraordinárias, e tem como objetivo manter os ecossistemas naturais de importância regional ou local e regular o uso admissível dessas áreas, de modo a compatibilizá-lo com os objetivos de conservação da natureza (BRASIL, 2000).

ß Floresta Nacional: de posse e domínio públicos, é uma área de cobertura florestal de espécies predominantemente nativas com o objetivo do uso sustentável e pesquisa científica. É permitida a visitação e a pesquisa é incentivada.

ß Reserva Extrativista: área utilizada por populações extrativistas tradicionais e tem como objetivos básicos proteger os meios de vida e cultura dessa população, articulado com o uso sustentável dos recursos naturais. É de domínio publico, mas com o uso concedido a essas populações.

ß Reserva de Fauna: áreas naturais com populações animais, adequadas para o estudo sobre o manejo econômico de elementos da fauna. A área é de domínio público, sendo proibida a caça e permitida a visitação de acordo com o plano de manejo da reserva.

ß Reserva de Desenvolvimento Sustentável: área natural que abriga populações tradicionais cuja existência está ligada a exploração sustentável dos recursos naturais. Tem como objetivo preservar a natureza e ao mesmo tempo garantir os meios necessários para a qualidade de vida dessas populações. É de domínio público e gerida 
por um Conselho Deliberativo, constituído por representantes de órgãos públicos, civis e da população tradicional.

B Reserva Particular do Patrimônio Natural: área privada, de caráter permanente, com o objetivo de conservar a diversidade biológica. O proprietário da área receberá orientação técnica e cientifica dos órgãos integrantes do SNUC para a elaboração do Plano de Manejo ou de Proteção e Gestão da área.

O Parque Nacional de Brasília enquadra-se nas Unidades de Proteção Integral, onde há a manutenção dos ecossistemas livre de alterações humanas, sendo admitido apenas o uso indireto de seus recursos naturais; na categoria de Parque Nacional, com visitação pública de acordo com o previsto no Plano de Manejo e pesquisas científicas tendo que ser previamente autorizadas. A unidade é de posse e domínios públicos, sendo que áreas particulares incluídas em seus limites deverão ser desapropriadas de acordo com a lei.

\section{O Parque Nacional de Brasília}

\subsection{Características Gerais}

O Parque Nacional de Brasília é uma Unidade de Conservação de proteção integral e encontra-se a aproximadamente $10 \mathrm{~km}$ do centro de Brasília, na porção noroeste do Distrito Federal. A entrada para visitantes (Zona de Uso Intensivo) situa-se na Estrada Parque Indústria e Abastecimento - EPIA. Existem outras entradas, com acesso exclusivo para serviço e controlado, inclusive a de acesso a Barragem de Santa Maria, que se situa dentro dos limites do Parque, sendo operada pela Companhia de Águas e Esgotos de Brasília - CAESB. O Parque conta com infra-estrutura de recepção e recreação, com duas piscinas formadas com a captação de águas minerais, lanchonetes, sanitários, trilhas ecológicas e o centro de visitantes. 
Mapa 1: Parque Nacional de Brasília - Localização

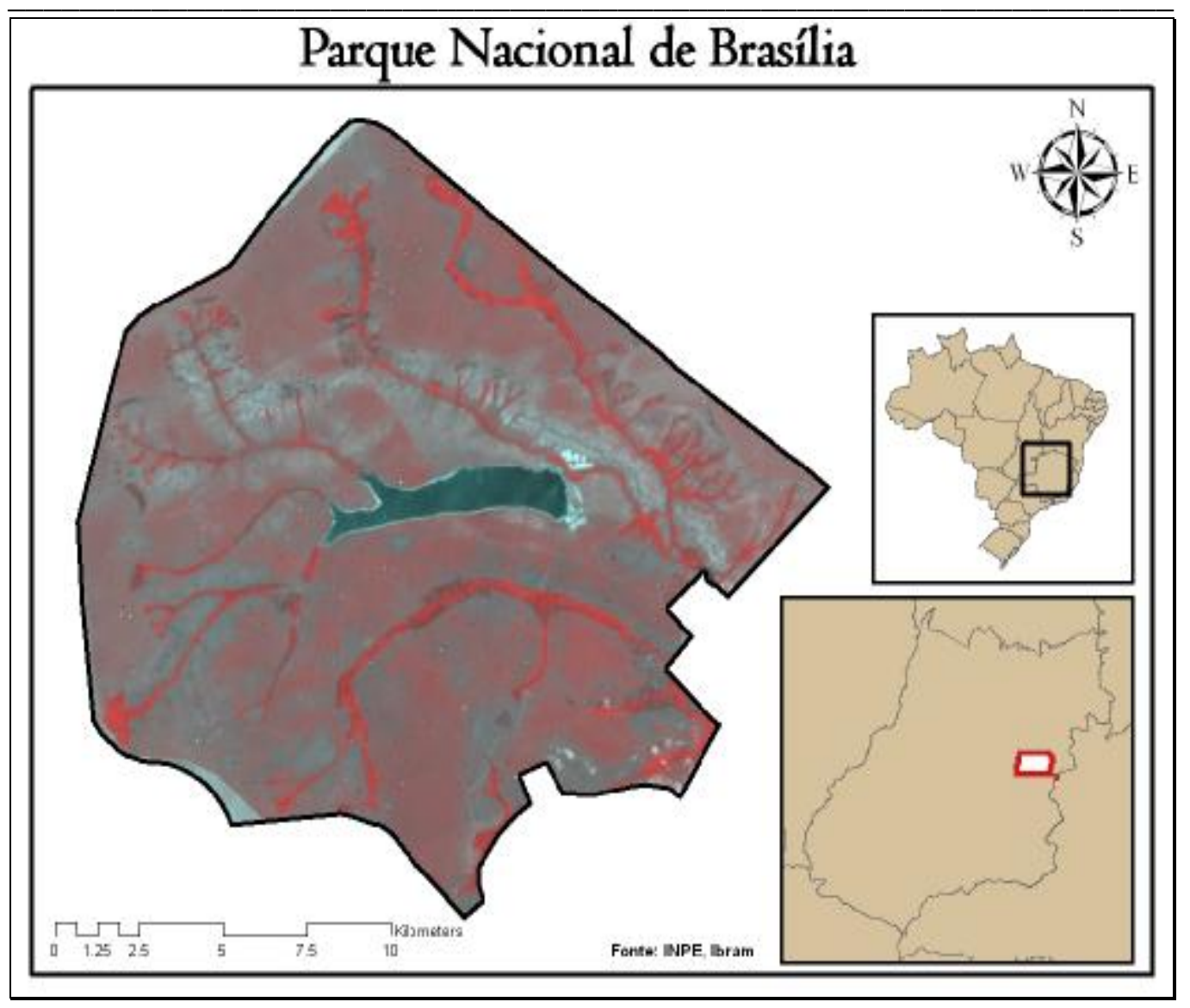

Um dos aspectos mais relevantes para a criação do Parque foi a questão da garantia de apropriação da água (ABDALA, 2002), recurso natural abundante na área e de importância estratégica para o Distrito Federal, já que a área do Parque engloba as bacias do rio do Torto e Bananal, que alimentam a barragem de Santa Maria. De acordo com o Plano de Manejo do Parque, "em termos de volume, as águas superficiais do sistema de captação das bacias do Córrego Santa Maria e Torto, contribuem atualmente com cerca de 20\% do abastecimento público do Distrito Federal" (FUNATURA, 1998).

O relevo do local é suave, variando de 1.070 metros a 1.200 metros. A área apresenta vários afloramentos de quartzitos com coloração variada. A unidade pedológica mais representada no Parque é a dos Latossolos (FUNATURA, 1998), apresentando também os Cambissolos, Solos Aluviais e Solos Hidromórficos. A vegetação é predominantemente de cerrado e suas variações, ocorrendo também a Matas Ciliares ao longo dos rios e córregos. No parque encontram-se várias espécies da fauna do cerrado, algumas ameaçadas de extinção como o lobo-guará, o veado-campeiro, os tatus-canastra e tatu-bola e o tamanduá-bandeira. 
Entre as espécies não ameaçadas encontram-se o sagui, o tapeti, o cachorro-do-mato, a capivara e diversas aves, além dos famosos macacos-prego, que atraem olhares curiosos dos visitantes.

O Parque Nacional de Brasília é o terceiro mais visitado do país, registrando-se mais de 800 mil visitantes/ano entre o público pagante, além de crianças menores de 10 anos e idosos acima de 65 anos, que são isentos. Entre os visitantes do parque podemos identificar 3 grupos: os praticantes de esportes, que vão ao parque quase diariamente; os membros de instituições, que vão ao parque com visitas pré-agendadas; e o público pagante comum, que utiliza o parque como área de lazer.

Mesmo com a grande quantidade de visitantes, pode-se dizer que a importância ambiental do Parque Nacional de Brasília é desconhecida, até nas classes mais cultas de Brasília, são poucos os que conhecem a real dimensão da área do parque e o fato de que a água que consomem provêm da represa de Santa Maria, localizada dentro do parque.

\subsection{Histórico do Parque}

A criação do Parque Nacional de Brasília está intimamente ligada a construção de Brasília. Criado pelo Decreto Federal n ${ }^{\circ}$ 241, assinado em 29 de novembro de 1961, o parque teve origem de um convênio mantido entre o Ministério da Agricultura e a NOVACAP Companhia de Desenvolvimento da Nova Capital, cujo objetivo era "propor e criar novas reservas e postos florestais".

No ano de 1960, quase no final do convênio firmado, o Dr. Hezechias Paulo Heringer, seu executor, viu a importância da criação de um Parque Nacional naquela área e elaborou uma exposição de motivos ao Presidente da República, na época Jânio Quadros, defendendo a criação do Parque Nacional de Brasília pelos seguintes motivos:

B A área é coberta por flora típica do cerrado, formação vegetal que ocupa mais de 1,5 milhões de $\mathrm{km}^{2}$ do Território Nacional, ou seja, mais de sua sexta parte, localizando-se Brasília no centro deste tipo de vegetação;

ß A área é rica em fauna típica da região, e são necessárias providências para que esta permaneça intacta;

B A topografia possui acidentes sui generis somente ali verificados, como nascentes de águas cristalinas, penhascos de arenito, fenômenos de "Karst" etc., que devem ser protegidos;

B A área inclui as bacias dos três rios fornecedores da água potável da capital. Trata-se, portanto de conseguir o domínio efetivo sobre as áreas destes mananciais e colocá-las à guarda de um organismo - o Parque Nacional de Brasília; 
B A manutenção desta área em estado natural contribuiria também para o equilíbrio das condições climáticas e evitar-se-ia a erosão do solo;

ß Finalmente considerava o Dr. Heringer o novo Parque como instituição educacional destinada a educar o povo nas práticas conservacionistas e servir para preservação de material básico para estudos e pesquisas. (FUNATURA, 1998)

Foi então instituído o Parque Nacional de Brasília com a área de 30.566 hectares (demarcado em 1996). No ano de 2006, foi aprovada a Lei $\mathrm{n}^{\circ} 11.285$ que alterou os limites do Parque, ampliando a área para 42.389,01 hectares. As áreas que passaram a fazer parte do Parque são situadas em trechos mais íngremes, onde se localizam cachoeiras, cavernas e pontos de interesse ambiental, excluindo áreas do projeto original como a Granja do Torto e o Núcleo Rural do Lago Oeste, por interesses econômicos e sociais, já que as áreas possuem residências e pequenas propriedades rurais.

\subsection{Plano de Manejo do Parque}

A Lei do Sistema Nacional de Unidades de Conservação - SNUC estabelece a obrigatoriedade de um Plano de Manejo para cada Unidade de Conservação, e estabelece o prazo de até cinco anos a partir da data de criação para a sua preparação e implementação. Esse documento deve ser composto de forma a ser o principal instrumento para o planejamento e a gestão da Unidade, não sendo o único instrumento necessário, mas a matriz de dados, projetos, programas e metas da gestão. A elaboração de um plano de manejo demanda no mínimo vários meses, para ser pesquisado, discutido e finalizado, exigindo a contratação de consultorias externas aos órgãos gestores, workshops, audiências públicas, trabalho de campo, tudo isso resultando em custos elevados.

O primeiro Plano de Manejo do Parque foi elaborado em 1978, mas o que está em vigor atualmente é o Plano elaborado pelo convênio IBAMA e FUNATURA - Fundação PróNatureza, do ano de 1998. O Plano atual está disponível apenas para a consulta na administração do Parque ou no Centro de Visitantes, por não existir uma versão em formato digital.

O Plano é dividido em encartes, no total de seis, onde encontramos no primeiro encarte as informações gerais da Unidade, no segundo, terceiro e quarto os contextos federal, estadual e regional respectivamente, no quinto uma caracterização da Unidade, seus aspectos físicos, culturais e institucionais, e no sexto encarte, o planejamento propriamente dito da 
Unidade de Conservação, com seus objetivos, diretrizes, zoneamentos e programas de manejo.

De acordo com o Plano de Manejo vigente, os objetivos específicos do Parque Nacional de Brasília são:

\footnotetext{
-Preservar amostras representativas das formações naturais e processos ecológicos do cerrado do Brasil Central.

-Proteger a fauna, flora e recursos genéticos do cerrado.

-Proteger as espécies da fauna e flora, com especial àquelas raras, endêmicas e ameaçadas de extinção que ocorrem no interior do PNB.

-Proteger feições hidrogeológicas específicas, geomorfológicas e sítios históricos, como: Peito de Moça, Três Buracos, estrada Real de Santa Luzia e acampamento da Comissão Cruls.

-Proporcionar e apoiar a pesquisa cientifica no Parque para o conhecimento e a proteção dos recursos naturais existentes.

-Contribuir com informações para o monitoramento dos processos ambientais e antrópicos, gerando parâmetros para o manejo e a mitigação de impactos ambientais. -Proporcionar oportunidades para recreação e atividades de lazer orientadas para o conhecimento e apreciação dos recursos naturais preservados no PNB, ao mesmo tempo divulgando junto aos visitantes a contribuição do Parque para a qualidade de vida da população.

-Contribuir para o disciplinamento do uso e ocupação territorial do entorno do parque.

-Promover a identificação, conscientização e a valorização do PNB pela população do Distrito Federal, através de práticas de Educação Ambiental.

- Contribuir para a manutenção da boa qualidade de vida no Distrito Federal.

-Garantir a proteção das áreas de recarga dos recursos hídricos das sub-bacias do Torto e Bananal localizadas no PNB.

-Contribuir para conservar o sistema do manancial hídrico Santa Maria/Torto, responsável pelo abastecimento de Brasília, protegendo a bacia hidrográfica, evitando a erosão e o assoreamento do reservatório.

-Contribuir para o monitoramento mundial de atividades sísmicas, por meio da presença de sensores interligados ao sistema mundial de monitoria desses fenômenos.

- Valorizar o Parque como ponto de congregação de esforços multisetoriais e holísticos para garantir a conservação do seu patrimônio natural e cultural da humanidade.

-Contribuir com informações técnicas para a recuperação de áreas degradadas (FUNATURA, 1998, p.6.2 e 6.3).
}

As diretrizes de planejamento foram definidas com base nos subsídios obtidos na Oficina de Planejamento, realizada no ano de 1998 com representantes de diferentes instituições e de segmentos da comunidade. Ocorreu também no mesmo ano, uma oficina interna, com os funcionários do Parque, o que auxiliou bastante fornecendo elementos para as recomendações de manejo e para as atividades a serem implementadas no Parque Nacional de Brasília. Segundo o Plano de Manejo, para que o Parque cumpra de maneira satisfatória seus objetivos, torna-se necessário: o conhecimento científico satisfatório sobre o Parque; o uso público adequado, através da educação ambiental e da recreação de forma eficiente e 
controlada; a integração do Parque com a sua área de influência, através da conscientização da população sobre a importância da Unidade; ter assegurada a integridade do patrimônio natural e um sistema operacional bem articulado.

\section{Procedimentos metodológicos}

Na elaboração deste trabalho utilizou-se de procedimentos metodológicos por meio de pesquisa bibliográfica e de campo. GIL (2002, p.44) define pesquisa bibliográfica como "o conjunto de materiais já elaborados, constituídos principalmente de livros e artigos científicos, escritos/gravados, mecânica ou eletronicamente, que contem informações já elaboradas e publicadas por outros autores". Foram pesquisados alguns conceitos julgados relevantes para a compreensão do tema e analisado o Plano de Manejo do Parque, importante instrumento para a gestão da Unidade. Em visita a área, foi disponibilizado um relatório de atividades do Núcleo de Educação Ambiental - NEA do Parque Nacional de Brasília, com dados das suas ações no ano de 2007, que também encontra-se neste trabalho.

A pesquisa de Campo é definida por GIL (2002) como aquela utilizada com o objetivo de reunir informações e conhecimentos acerca de certo problema para o qual se procura uma resposta, ou de uma hipótese que se queira comprovar. Esse trabalho utilizou-se de uma abordagem quantitativa, porém buscando também alguns elementos qualitativos, através de entrevistas semi-estruturadas.

\subsection{Dados da Pesquisa}

A pesquisa foi realizada na zona de uso intensivo do Parque Nacional de Brasília, principalmente nos arredores das piscinas, nos dias 7 e 8 de agosto de 2009. Participaram da pesquisa 200 usuários do Parque, de diferentes classes econômicas e níveis de escolaridade, a maioria entre 26 e 45 anos. Os dados foram coletados através de questionários, que possuíam questões abertas e fechadas, a fim de avaliar o conhecimento dos freqüentadores e a importância que eles atribuem ao Parque.

\subsection{Análise e Discussão dos Dados}

A análise dos dados foi realizada com base nas respostas obtidas nos questionários aplicados para os usuários do Parque, utilizando tabelas e gráficos para melhor visualização 
das respostas obtidas. A amostra é constituída por indivíduos bem heterogêneos, dando preferência aos usuários adultos, principal foco deste trabalho. Dentre os entrevistados, 124 eram do sexo feminino e 76 do sexo masculino. Os outros dados demográficos encontram-se nas tabelas abaixo:

Tabela 1: Faixa Etária dos Entrevistados.

\begin{tabular}{|l|c|c|}
\hline Variáveis & Frequência & Porcentagem (\%) \\
\hline Até 25 anos & 40 & 20 \\
\hline Entre 26 e 35 anos & 54 & 27 \\
\hline Entre 36 e 45 anos & 53 & 26,5 \\
\hline Entre 46 e 60 anos & 35 & 17,5 \\
\hline Acima de 61 anos & 18 & 9 \\
\hline Total & 200 & 100 \\
\hline
\end{tabular}

Fonte: Pesquisa de campo, realizada em agosto de 2009 por Camila Almeida.

Tabela 2: Escolaridade dos Entrevistados.

\begin{tabular}{|l|c|c|}
\hline Variáveis & Frequência & Porcentagem (\%) \\
\hline Ensino Fundamental Incompleto & 9 & 4,5 \\
\hline Ensino Fundamental & 18 & 9 \\
\hline Ensino Médio Incompleto & 28 & 14 \\
\hline Ensino Médio & 53 & 26,5 \\
\hline Ensino Superior Incompleto & 43 & 21,5 \\
\hline Ensino Superior & 49 & 24,5 \\
\hline Total & 200 & 100 \\
\hline
\end{tabular}

Fonte: Pesquisa de campo, realizada em agosto de 2009 por Camila Almeida.

Quanto à ocupação ou profissão dos visitantes do Parque, obtemos as respostas mais variadas: a maior categoria foi a dos professores (37), seguida de servidores públicos (30), estudantes (25),comerciantes (23), profissionais da saúde (17), desempregados (17), aposentados (14), diaristas (13), policiais militares (7) entre outros (14).

Após os dados demográficos foi aplicado um questionário sobre a relação dos usuários com o Parque Nacional, a fim de avaliar sua visão sobre a área e a relação dos visitantes com o Parque. Na primeira questão foi perguntado aos usuários se conheciam outro nome da área que estavam além de Parque da Água Mineral. Dos visitantes apenas 36\% sabiam que estavam no Parque Nacional de Brasília, os outros $64 \%$ utilizam a área sem saber a sua real importância ambiental. 
A segunda questão foi referente a frequência de visitação dos usuários, observando o gráfico podemos notar que a maioria dos visitantes são frequentes, e mesmo não sabem que se encontram em uma Unidade de Conservação.

Gráfico 1: Percentual da frequência dos visitantes do PNB

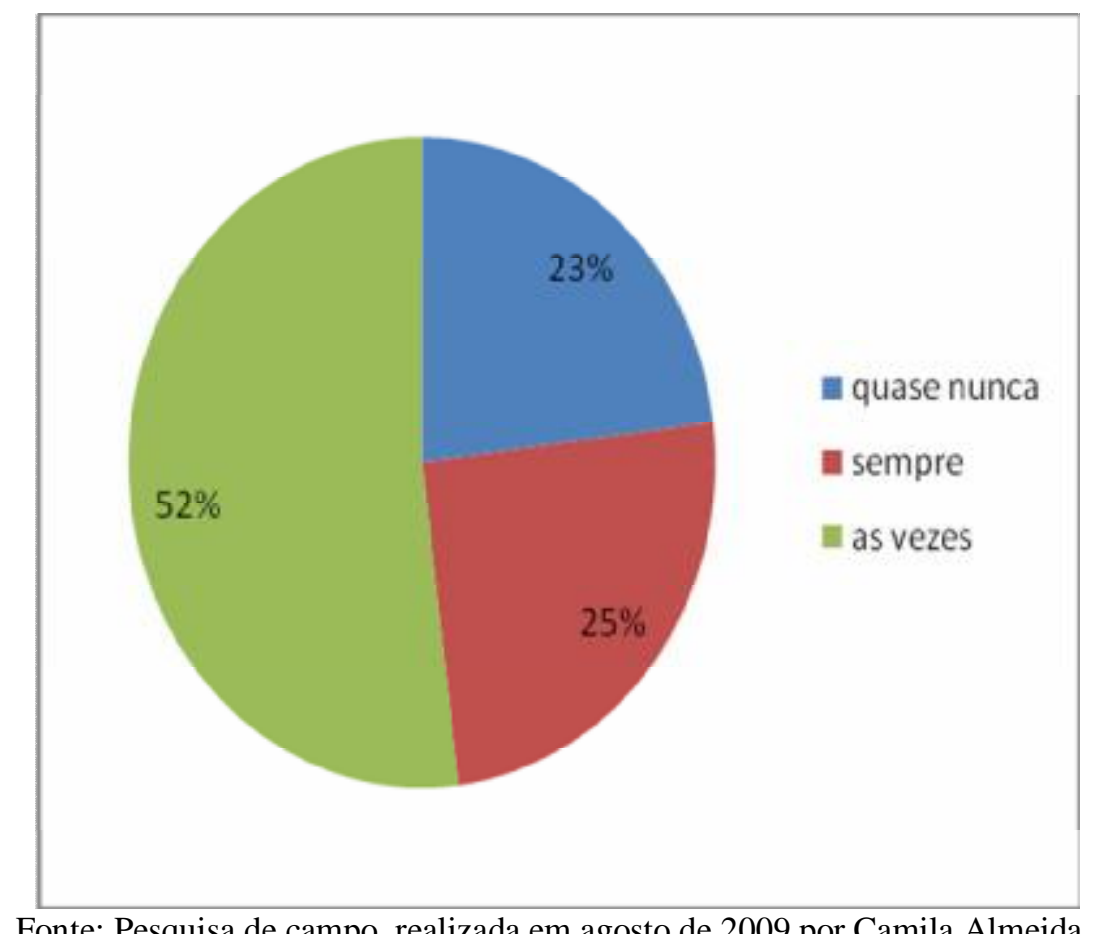

Fonte: Pesquisa de campo, realizada em agosto de 2009 por Camila Almeida.

Quando perguntados sobre o que já visitaram no parque (questão 3), foram dadas três opções podendo ser marcada mais de uma, e um espaço para outras áreas não discriminadas, pedindo para que, caso existam essas áreas, o usuário relate quais são. As piscinas foram unanimidade, sendo visitadas por $100 \%$ dos entrevistados, seguidas das trilhas, visitadas por 86,5\%. Apenas $46 \%$ dos entrevistados afirmaram que já visitaram o Centro de Visitantes, muitos usuários desconheciam a sua existência até o momento da entrevista, afirmando a falta de informação sobre este Centro. Nenhum dos entrevistados citou alguma outra área visitada dentro do parque.

Sobre a repercussão do Parque Nacional de Brasília nas mídias (questão 4), perguntamos aos entrevistados se já ouviram ou leram notícias a respeito, foram usadas as graduações nunca, raramente, as vezes e quase sempre nesta questão. 
Gráfico 2: Percentual de entrevistados que leram ou ouviram alguma noticia sobre o PNB

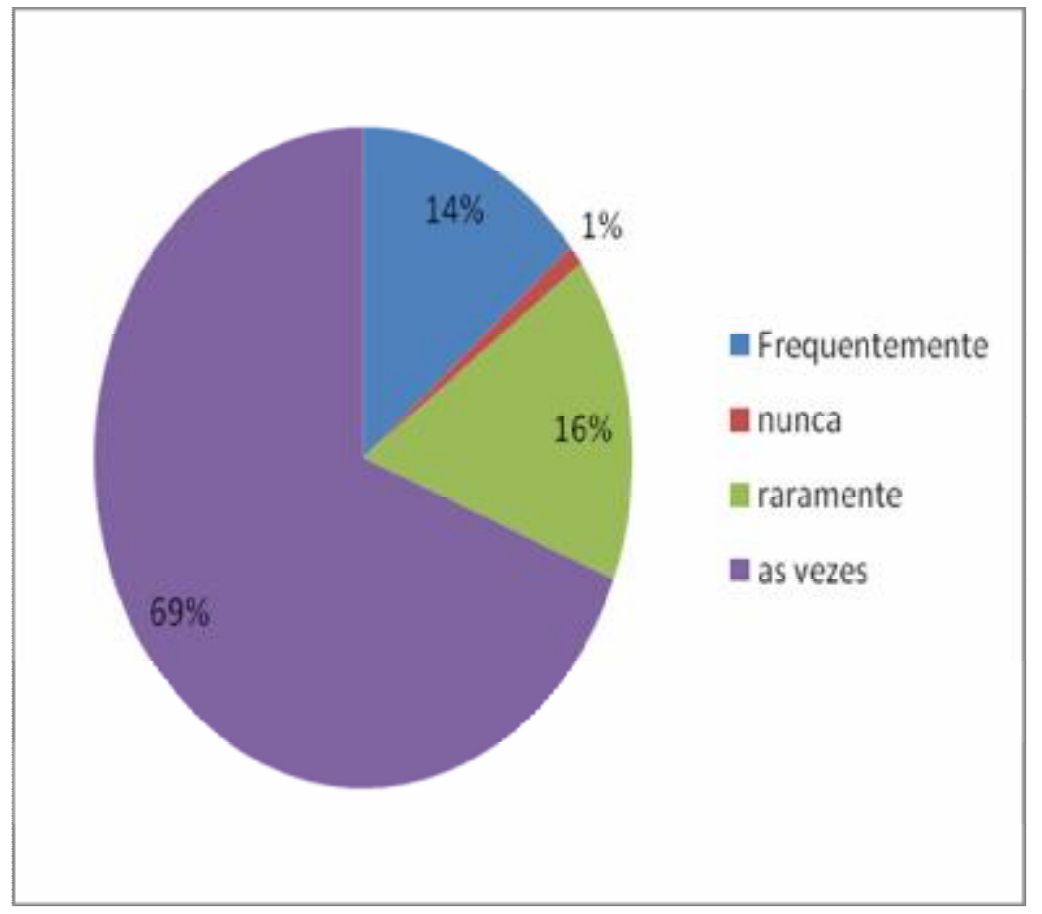

Fonte: Pesquisa de campo, realizada em agosto de 2009 por Camila Almeida.

A quinta questão consistiu em uma questão aberta, onde foi perguntado para os usuários do parque qual a sua opinião sobre a importância do Parque Nacional de Brasília, as respostas dos entrevistados foram:

Tabela 3: Importância do PNB segundo os entrevistados.

\begin{tabular}{|l|c|}
\hline Aspectos citados & $\begin{array}{c}\text { Total de } \\
\text { citações }\end{array}$ \\
\hline Lazer & 127 \\
\hline Saúde & 72 \\
\hline Preservação & 140 \\
\hline Educação Ambiental & 2 \\
\hline Abastecimento de Água & 1 \\
\hline Área verde & 23 \\
\hline Conscientização & 12 \\
\hline
\end{tabular}

Fonte: Pesquisa de campo, realizada em agosto de 2009 por Camila Almeida.

Nota-se que grande parte dos entrevistados associam a área do parque a preservação ambiental, mas sem saber ao certo a sua real importância. Para grande parte da população a preservação da área está associada a não deixar lixos espalhados pela área e não alimentar os micos, principais recomendações recebidas pelos visitantes. O lazer e a saúde da população que freqüenta o parque vem em seguida, dando a falsa impressão de que a área é um clube, 
voltado principalmente para populações carentes. Apenas um entrevistado citou a questão do abastecimento de água do Plano Piloto, recorrente da represa de Santa Maria, e 23 usuários citaram o parque como sendo uma área verde próxima a cidade, trazendo benefícios a população que reside próxima a área.

A sexta questão era relacionada com os problemas enfrentados pelo parque. Os entrevistados foram questionados sobre a existência de algum problema, não apenas no ponto de vista ambiental, deixando a questão aberta a várias interpretações. Dos usuários 58, o que corresponde a $29 \%$ dos entrevistados alegaram não conhecer problemas enfrentados pelo parque. Entre os 142 usuários que assinalaram a alternativa positiva, o que corresponde a $71 \%$ dos entrevistados, foram listados os seguintes problemas:

Tabela 4: Problemas enfrentados pelo PNB segundo os entrevistados.

\begin{tabular}{|c|c|}
\hline Problemas listados & $\begin{array}{c}\text { Total de } \\
\text { citações }\end{array}$ \\
\hline Limpeza da água & 18 \\
\hline Invasões & 2 \\
\hline Lixo & 120 \\
\hline Alimentar animais & 112 \\
\hline Falta de recursos financeiros & 1 \\
\hline Queimadas & 61 \\
\hline Morte de animais & 54 \\
\hline Insegurança nas trilhas & 5 \\
\hline Especulação imobiliária & 1 \\
\hline
\end{tabular}

Fonte: Pesquisa de campo, realizada em agosto de 2009 por Camila Almeida.

A grande maioria citou o lixo como um dos problemas enfrentados pelo parque. Alguns relacionaram com os entulhos lançados na área do parque por moradores do entorno, mas a grande maioria se referia ao lixo deixado pelos frequentadores que usam a zona de uso intensivo da unidade. Ainda entre os problemas causados por usuários vimos um elevado número de visitantes que citaram o costume de alimentar os micos que habitam no parque como um problema enfrentado. Outros problemas bastante citados foram as queimadas e morte de animais silvestres, que estão muito presentes na mídia, principalmente televisiva, em algumas épocas do ano. Houve dezoito citações sobre a limpeza das águas das piscinas do parque, alguns usuários relataram a presença de fezes e dejetos lançados pelos próprios visitantes nas piscinas e suas imediações. Alguns usuários levantaram a questão da insegurança nas trilhas, sendo registrado por um deles um caso de assalto, além de usuários de 
drogas que se utilizam da área e acabam intimidando os freqüentadores. Um dos entrevistados citou a falta de recursos financeiros como um problema do Parque, porém quando questionado, não soube responder de que fonte ouviu esta notícia.

Duas respostas interessantes, porém pouco frequentes foram as invasões e a especulação imobiliária ao redor do Parque Nacional. Os entrevistados que citaram as invasões (dois deles) citaram a falta de vigilância nos limites do parque como principal causa. Sobre a especulação imobiliária, a entrevistada citou a questão da valorização das residências próximas a áreas verdes, que vem aumentando atualmente com a preocupação com o bem estar, e citou a construção do Setor Noroeste como um exemplo de especulação na área.

A sétima questão era se os entrevistados já receberam algum tipo de orientação sobre a importância do Parque e como ajudar na sua preservação. O percentual de respostas negativas foi alto, $69,5 \%$ dos entrevistados alegaram não ter recebido nenhum tipo de orientação sobre o parque, o que significa 139 usuários numa amostra de 200. Entre os que responderam positivamente, 32 receberam a orientação em visita ao Centro de Visitantes do Parque; 18 deles receberam orientações foram da unidade, em outras instituições, sendo no trabalho, escola ou faculdade; oito receberam esclarecimentos ao pedirem a funcionários do Parque a paisana; e três deles afirmaram que leram algumas informações em placas espalhadas pela área, mas nunca foram instruídos verbalmente sobre a Unidade de Conservação.

$\mathrm{Na}$ oitava questão foi perguntado aos entrevistados se algum deles teria tempo disponível ou interesse em auxiliar na preservação do Parque. As alternativas eram: 1- Não, não tenho tempo disponível ou interesse; 2- Sim, tenho interesse mas não tenho tempo disponível; 3- Sim, tenho interesse e tempo disponível. Entre as respostas, apenas 13\% afirmaram não ter tempo ou interesse em auxiliar no Parque, demonstrando total desinteresse em ajudar na preservação. 
Gráfico 3 : Percentual de Interessados em auxiliar na preservação do PNB

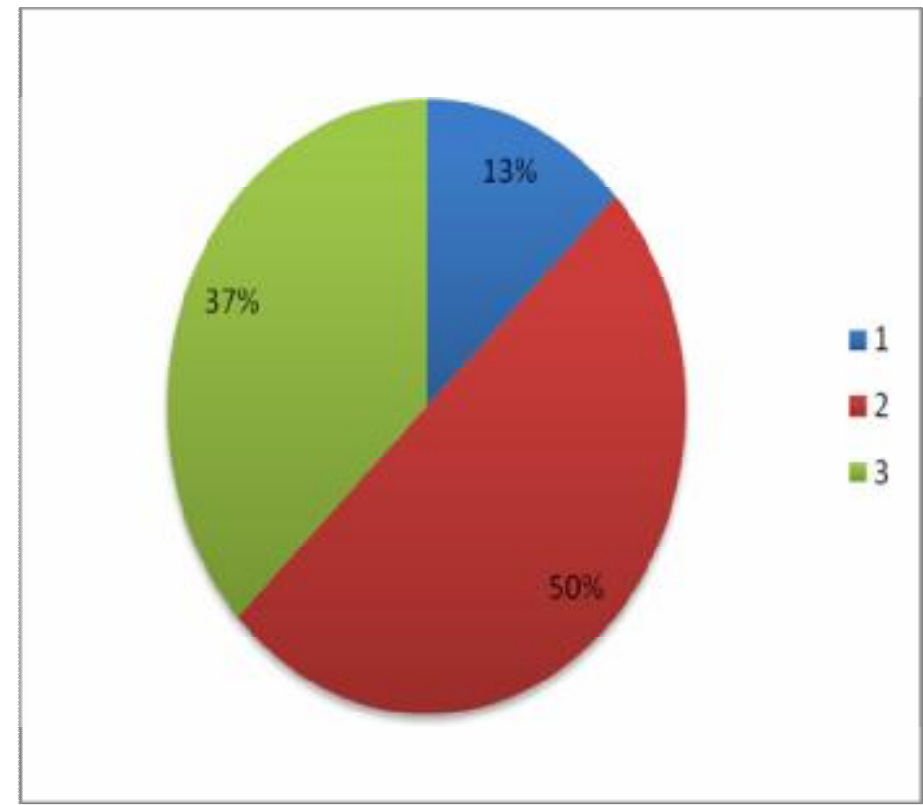

Fonte: Pesquisa de campo, realizada em agosto de 2009 por Camila Almeida.

Como mostra o gráfico, metade dos entrevistados afirmou ter interesse em auxiliar na preservação do parque de alguma forma, porém não encontram tempo disponível para tal tarefa. Os que afirmaram ter tempo disponível e interesse em ajudar somaram $37 \%$ do total dos entrevistados, número bastante relevante, já que mesmo demonstrando esse interesse nenhum deles é voluntário ou já ajudou de alguma forma no parque. Esta amostra é importante para mostrar que existem usuários do parque dispostos a ajudar no manejo da área, pessoas que deveriam ser alvo de programas de preparação e orientação para serem multiplicadores de conhecimento dentro e fora dos limites da Unidade.

Ainda no tema da questão anterior, a nona pergunta é sobre como cada um acha que poderia contribuir com o Parque. A questão é aberta e os entrevistados podem responder como lhe for conveniente, o que deixa alguns em dúvida, totalizando 13 o número dos que não responderam essa questão. Entre as respostas não encontramos muitas variações, o que mostra que realmente a população não sabe o que pode fazer para ajudar na preservação da área, sendo citadas as seguintes ações: 
Tabela 5: Formas de contribuir com o PNB segundo os entrevistados.

\begin{tabular}{|l|c|}
\hline Ações Listadas & Total de Citações \\
\hline Não jogar lixo na área & 127 \\
\hline Não alimentar os micos & 90 \\
\hline Trabalhar como Educador Ambiental & 131 \\
\hline Preservar o Parque & 93 \\
\hline
\end{tabular}

Fonte: Pesquisa de campo, realizada em agosto de 2009 por Camila Almeida.

A visão que encontramos aqui é que para auxiliar na preservação do Parque basta fazer a sua parte, recolher o lixo, não alimentar os animais e nem depredar a área. De certa forma é um avanço, mostrando que a população sabe o que fazer para conservar a área de uso comum agradável para a visitação, porém não conhecem a real dimensão dos problemas ambientais enfrentados pelo parque. Nota-se um grande número de entrevistados que citaram a Educação Ambiental como forma de auxiliar na preservação do Parque, alguns deles demonstraram interesse em fazer algum curso na área e alguns professores entrevistados afirmaram ter feito o curso de Educador Ambiental oferecido pelo Núcleo de Educação Ambiental do Parque Nacional de Brasília.

Na décima questão, perguntamos aos visitantes do Parque se sabem qual a relação existente entre a Barragem de Santa Maria e o Parque Nacional de Brasília. As respostas negativas somaram $81 \%$, demonstrando que grande maioria da população desconhece os benefícios que o Parque trás para a sociedade brasiliense. Dos $19 \%$ que responderam positivamente, $68,5 \%$ relacionaram a barragem com o abastecimento de água de Brasília, os outros $34,2 \%$ disseram que as águas da barragem servem para encher as piscinas da Água Mineral.

Pode-se concluir desta pesquisa que a população em geral desconhece a real importância do Parque Nacional de Brasília, no geral todos afirmam que a área deve ser preservada, mas não sabem a real dimensão que os impactos sofridos na Unidade podem trazer para Brasília. Nota-se na maioria um interesse em conservar a área, seja para manter um centro de lazer disponível para os fins de semana ou por motivos ambientais. Em alguns esse interesse é maior, tendo um numero significativo de usuários dispostos a gastar um pouco do seu tempo para ajudar de alguma forma no manejo do parque. Torna-se necessário a disseminação de informações e treinamento para que essas pessoas possam de algum modo contribuir para o melhor funcionamento dessa Unidade de Conservação. 


\section{Programas de Educação Ambiental e inclusão da População no Parque}

Segundo o SNUC - Sistema Nacional de Unidades de Conservação, uma das funções das unidades de conservação é "favorecer condições e promover a educação e interpretação ambiental" (BRASIL, 2000).

O parque possui um Núcleo de Educação Ambiental - NEA, que tem como missão "atuar para a formação de uma consciência sócio-ambiental, comprometida com a ética e os valores humanos, na promoção do Desenvolvimento de Sociedades Sustentáveis" (DIAS, 2004, p. 69). O programa de Educação Ambiental do Núcleo de Educação Ambiental do PNB tem como Marco Conceitual as recomendações da Política Nacional de Educação Ambiental e observa ainda as recomendações da Diretoria de Educação Ambiental do IBAMA. Segundo essas premissas, o ambiente é visto em sua totalidade, superando a visão reducionista, meramente biológica, para configurar-se em dimensões socioambientais.

A missão do Núcleo de Educação Ambiental é atuar para a formação de uma consciência socioambiental, comprometida com a ética e os valores humanos na promoção do desenvolvimento de sociedades sustentáveis. Dentre os vários princípios desse núcleo podemos destacar: a valorização de uma sociedade democrática, ambientalmente correta e socialmente justa; a promoção da sustentabilidade do Parque Nacional de Brasília; utilizar recursos naturais e matérias de consumo de forma parcimoniosa; observar as orientações das políticas públicas: Legislação Ambiental, Sistema Nacional de Unidades de Conservação, Política Nacional de Educação Ambiental.

Segundo o Relatório de Atividades de 2007 conseguido no NEA do Parque Nacional de Brasília, o Programa de Educação Ambiental - PEA atendeu 17.992 pessoas. Destas, 4.948 foram alunos da rede de ensino do Distrito Federal e Entorno, atendidos no Centro de Visitantes, e 7.614 foram atendidos em atividades no Entorno (exposições, feiras). Foram oferecidos 17 cursos para formação de professores e monitores, a fim de que eles possam transmitir para seus alunos os conhecimentos adquiridos sobre o Parque. O curso é um prérequisito para que os professores e multiplicadores possam trazer seus alunos ao Parque. Participaram dos cursos um total de 690 educadores, o que resultou no atendimento de 53 escolas e 3 universidades. As escolas públicas representaram em 2007 94,7\% das escolas que visitaram o Parque. Os visitantes espontâneos foram 5.792, de 18 estados brasileiros e 56 
visitantes de 19 países diferentes. Os membros do NEA proferiram 4 palestras, beneficiando um total de 550 pessoas.

Tabela 6: Visitantes Espontâneos (Brasil) que frequentaram o Centro de Visitantes e assinaram o Livro em 2007

\begin{tabular}{|l|r|}
\hline Procedência & Total \\
\hline Alagoas & 2 \\
\hline Amazonas & 16 \\
\hline Bahia & 48 \\
\hline Ceará & 33 \\
\hline Distrito Federal & 4.834 \\
\hline Espírito Santo & 8 \\
\hline Goiás & 458 \\
\hline Maranhão & 39 \\
\hline Mato Grosso & 16 \\
\hline Minas gerais & 91 \\
\hline Paraná & 31 \\
\hline Pernambuco & 18 \\
\hline Piauí & 11 \\
\hline Rio de Janeiro & 100 \\
\hline Rio Grande do Norte & 13 \\
\hline Rio Grande do Sul & 8 \\
\hline Santa Catarina & 17 \\
\hline São Paulo & 49 \\
\hline Total & $\mathbf{5 . 7 9 2}$ \\
\hline
\end{tabular}

Fonte: Relatório de Atividades do NEA - 2007

Tabela 7: Visitantes Espontâneos de outras nações que frequentaram o Centro de Visitantes e assinaram o Livro em 2007.

\begin{tabular}{|l|r|l|r|}
\hline Países & Total & Países & Total \\
\hline Alemanha & 1 & Itália & 3 \\
\hline Argentina & 2 & Japão & 6 \\
\hline Austrália & 1 & Noruega & 1 \\
\hline Iraque & 2 & África & 3 \\
\hline Canadá & 1 & Portugal & 3 \\
\hline Espanha & 2 & Nicarágua & 2 \\
\hline Estados Unidos & 11 & Palestina & 1 \\
\hline França & 3 & Uruguai & 2 \\
\hline Holanda & 2 & Paraguai & 2 \\
\hline Inglaterra & 8 & Total & $\mathbf{5 6}$ \\
\hline
\end{tabular}

Fonte: Relatório de Atividades do NEA - 2007 
O Parque Nacional de Brasília em parceria com o Ministério Público do Distrito Federal e Territórios - MPDFT resultou na realização de 2 cursos destinados aos Autores de Ilícitos Ambientais e urbanísticos, contemplando 72 participantes. O curso foi idealizado pela equipe de educação ambiental a partir da demanda proveniente do MPDFT com infratores de delitos ambientais e urbanísticos com direito a cumprirem penas alternativas. Destes que fizeram o curso, 28 autores de Ilícitos prestaram serviços voluntários, conforme acordo estabelecido com a Promotoria de Defesa do Meio Ambiente (PRODEMA/MPDFT).

Além do atendimento a escolas, o parque também atende a instituições públicas e privadas, como hospitais, prefeituras e casas de ação social. Em 2007 foram atendidas 5 instituições, sendo 4 delas instituições públicas, atingindo 419 pessoas atendidas. Entre as atividades no Entorno, merecem destaque o Projeto "O Parque Vai a Sua Escola”, que tem como objetivo integrar os alunos do entorno do Parque e das outras Unidades de Conservação próximas (Floresta Nacional e Reserva Biológica da Contagem), usando a metodologia do lúdico e do vivenciar, trazendo-os a esta Unidade de Conservação, e o projeto Leitura no Parque, que atinge adolescentes entre 12 e 17 anos que vivem no entorno do Parque. Além de incentivar a leitura, esse programa também mostra a importância do cerrado e dos recursos existente no Parque. Com o programa O Parque vai a sua escola foram atendidos 1.512 alunos de 3 escolas, e com o Projeto leitura no Parque, 212 alunos de 6 escolas.

Foram realizados trabalhos no entorno do Parque com o objetivo de estreitar as relações entre os representantes dos condomínios próximos a área e os representantes do Parque, a fim de mostrar a importância da comunidade na preservação. Acontecem também exposições itinerantes, que atendem a demandas solicitadas por outras instituições. Geralmente são montadas em locais que apresentam um potencial para a multiplicação de conceitos básicos de meio ambiente. Foram realizados 5.800 atendimentos em 2007 em exposições itinerantes.

\section{A inclusão da População como alternativa no manejo da área}

\subsection{Problemas e dificuldades do Parque}

O Parque Nacional encontra-se em uma área de grande pressão urbana, cercado de atividades que causam risco a sua integridade. Segundo Salgado (2002), os impactos causados pelos usos e ocupações são sofridos em cadeia: iniciam-se com alterações na vegetação, 
atingindo depois a fauna e os recursos hídricos. Podemos citar diversas situações e consequências das atividades que ocorrem nos arredores do Parque Nacional de Brasília, dentre elas:

B Devido a destruição ou fragmentação de habitats, resultante de edificações ou de loteamentos, ocorre a repulsão para outras áreas, a eliminação ou o isolamento de algumas espécies da fauna, causando o empobrecimento genético dessas espécies e a sua redução, já que a redução do habitat trás como consequência a falta de recursos alimentícios.

ß Atração da fauna para as áreas de cultivos de alimentos. Com a falta de recursos alimentícios e a proximidade das plantações humanas, essas espécies são atraídas para áreas agrícolas, muitas vezes tornando-se um problema para os produtores e sendo facilmente visadas para a caça. Esses animais podem ainda sofrer intoxicações por consumirem produtos inapropriados ou alimentos com biocidas.

B Entrada de espécies vegetais e animais exóticas. Podemos citar os animais domésticos na área do parque, como exemplo os cães, que muitas vezes formam bandos e atacam as espécies da fauna local, e a dispersão para o interior do parque de espécies vegetais exóticas, plantadas nos derredores, causando o desequilíbrio ambiental e a ameaçando algumas espécies da flora local.

B Retirada da cobertura vegetal, acarretando perda de fertilidade e empobrecimento do solo, aceleração dos processos erosivos, aumento da poluição e do assoreamento dos rios, redução na biodiversidade, alteração na velocidade dos ventos, aumento na temperatura do ar e modificando, irreversivelmente, o microclima local.

B A construção e pavimentação em áreas próximas, ou o pisoteamento do solo, que causam a compactação e a impermeabilização do mesmo, dificultando a infiltração e aumentando o escoamento superficial das águas da chuva, prejudicando a saturação superficial dos solos e o abastecimento doa aquíferos subterrâneos. Os reservatórios de aquíferos também diminuem devido ao excessivo consumo de águas subterrâneas, pelo uso indiscriminado de poços, cisternas.

ß Aumento da produção e acúmulo de resíduos sólidos (entulho) ou líquidos (óleos e combustíveis), em locais inapropriados, tornando-se fonte de doenças para animais e 
humanos, poluindo o solo e os cursos d'água, atingindo muitas vezes até as águas subterrâneas através da infiltração.

Além dos problemas gerados nas imediações do Parque, existem problemas resultantes das visitações, principalmente nos feriados e finais de semana dos períodos mais secos. Apesar de a Unidade ter em seu plano de manejo a visitação restrita a 3.000 visitantes/dia, a sua capacidade é excedida, principalmente nas imediações da piscina velha, já que, de acordo com a administração do Parque, limitar o acesso de pessoas ao local é uma tarefa difícil, pois a iniciativa não é bem aceita e muitas vezes, causa de hostilidade dos visitantes e comunidade em geral.

Embora haja diversas atividades com o propósito de sensibilizar a população sobre a importância do parque, o principal espaço que poderia ser utilizado para esse fim não atende as expectativas. As exposições do Centro de Visitantes não se mostram atraentes para a população em geral. Apenas visitantes previamente agendados são acompanhados por funcionários do parque, os demais circulam pela exposição sem receber nenhum tipo de orientação e informações relevantes sobre a área. Outro fator é a localização do Centro, longe da área usual de circulação dos visitantes, salvo alguns que utilizam as vias internas para caminhada e corrida, além da falta de divulgação do Centro de Visitantes, sendo grande o número de usuários da área que nem conhecem a sua existência.

\subsection{Resultados alcançados e soluções possíveis com o apoio da população}

O trabalho voluntário encontra-se cada vez mais aparente nas notícias em geral. Sendo de cunho social ou ambiental, tem sido visto com bons olhos as iniciativas de ONGs ou de cidadãos em prol de alguma causa. Em contrapartida o que se vê por parte dessa população envolvida, são ações esporádicas e de efeito temporário, como por exemplo, mutirões para recolher o lixo de certas áreas. Não que essas ações não tenham seu valor, mas o envolvimento com uma Unidade de Conservação vai muito além disso.

No que toca as iniciativas ambientais voluntárias no Brasil, pouco tem sido feito pelos órgãos institucionais para incorporar essas práticas ao planejamento e a rotina dos Parques Nacionais. Como podemos ver pela pesquisa realizada, há um número relevante de cidadãos dispostos a doar uma parcela de seu tempo em prol da realização de um ideal. Para que esta parcela da população possa auxiliar na preservação e manejo da Unidade, tornam-se 
necessários cursos preparatórios a fim de maximizar o potencial de cada um deles, tornando o trabalho voluntário muito mais proveitoso.

Entre os entrevistados no Parque Nacional de Brasília, notamos uma grande quantidade de educadores e formadores de opinião, principalmente junto a crianças e adolescentes. Esse seria o principal público alvo de cursos de para educadores ambientais, como o que existe no Núcleo de Educação Ambiental do Parque, curso pouco conhecido e que não é divulgado para os visitantes do parque.

De acordo com o relatório de atividades do Parque, as atividades de Educação Ambiental realizadas, atingiram principalmente alunos da rede pública de ensino do Distrito Federal e a algumas comunidades no entorno do parque. Para os visitantes do parque, as ações ambientais deixam a desejar, fazendo com que a população não conheça a real importância da área, utilizando-a só para o lazer.

Com o apoio da população, seria possível ações como as existentes em vários parques espalhados pelo mundo. No Rio de Janeiro o Grupo Terra Limpa atua em áreas onde não há a devida atenção das autoridades responsáveis pela sua preservação, realizando atividades de limpeza, instalação de placas indicativas e educativas, distribuição de sacos plásticos para o lixo e de folhetos, além do fechamento de atalhos que causavam erosões. Na Austrália, onde o setor voluntário congrega dois milhões de pessoas e poupa aos cofres públicos o equivalente anual a 3,5 bilhões de dólares de trabalho remunerado, atividades de erradicação de espécies exóticas, replantio de mata nativa e educação ambiental são feitas em sua maior parte por essa mão de obra.

Mesmo com tantas experiências positivas espalhadas pelo mundo, há no Brasil um certo receio no que diz respeito ao trabalho voluntário. Segundo alguns funcionários do Parque Nacional de Brasília, não há interesse nem entusiasmo da população em trabalhar gratuitamente na área. A hipótese pode ser descartada através dos resultados da pesquisa, que mostram que na realidade falta uma preparação para que este público possa atuar de alguma forma no Parque Nacional.

A questão do voluntariado envolve muito mais do que uma relação empregadorística. $\mathrm{O}$ voluntário se sente parte daquela Unidade de Conservação, o que resulta em maiores cobranças da direção do Parque, resultando diversas vezes em conflitos que na maioria dos 
casos atingem a Unidade positivamente, já que passa a congregar em torno de si um grupo de cidadãos com ela imensamente comprometidos.

O primeiro passo para se obter um trabalho voluntário de qualidade é possuir na estrutura da Unidade de Conservação um profissional treinado para lidar com as peculiaridades deste tipo de mão de obra. Mesmo que o voluntário tenha um alto grau de comprometimento com o Parque, ele também possui suas atividades profissionais remuneradas. Assim, nem sempre será possível contar com a sua presença nos momentos necessários, o que torna essencial um planejamento flexível para que se possa atingir os objetivos esperados.

O benefício da inclusão da população no manejo do Parque Nacional de Brasília não se resume a economia de recursos financeiros, mas é acrescido do aumento da consciência ambiental e da compreensão por parte dos voluntários dos difíceis processos de gestão de uma área protegida, funcionando para eles como um grande processo de educação ambiental. Vários problemas enfrentados pelo Parque e citados aqui neste trabalho podem ser solucionados ou minimizados com o auxilio da população, se os governantes e responsáveis deixarem de lado a visão de que o trabalho voluntário e a inclusão da população na preservação não passam de utopias. 


\section{Considerações Finais}

A presente pesquisa proporcionou conhecer um pouco mais a relação dos visitantes com o Parque Nacional de Brasília. Para alguns usuários, a área não passa de uma opção de lazer, praticamente a única para algumas famílias de baixa renda. Outros já conseguem perceber, mesmo que precariamente, a importância ambiental dessa Unidade, mas são poucos os que reconhecem a real dimensão de seus limites e a grande relevância do Parque Nacional para a população do Distrito Federal.

Entre os visitantes do Parque, nota-se que poucos foram orientados de alguma forma sobre a importância da área para o Distrito Federal. Sem esse conhecimento, despertar o interesse da população em auxiliar de alguma forma na preservação da área fica muito mais difícil. Torna-se necessário um maior investimento dos responsáveis em ações de conscientização principalmente dos visitantes do Parque, que seriam os maiores interessados em manter a qualidade dessa Unidade de Conservação.

Notamos na pesquisa feita, que o conceito de preservação é utilizado pelos visitantes mas sem saber o seu real significado em relação ao parque, desconhecendo a dimensão que os impactos sofridos pelo Parque Nacional de Brasília podem trazer ao Distrito Federal. A maioria dos entrevistados, afirmaram ter interesse em ajudar de alguma forma na preservação da área, tanto para manter o Parque um lugar agradável à visitação e ao lazer, ou por possuírem uma visão da importância ambiental da área. É necessário conhecer essa parcela da população disposta a auxiliar, dentro de suas possibilidades, no manejo do Parque Nacional de Brasília, para que se possa utilizar os recursos humanos existentes de maneira eficaz, tornando essa atividade prazerosa aos voluntários.

A Educação Ambiental é de suma importância nesse processo de formação de voluntários, sendo necessária para a disseminação de informações relevantes sobre a Unidade de Conservação e para despertar um interesse maior por parte dos frequentadores do Parque na sua preservação.

O investimento neste tipo de trabalho é pequeno se comparado aos benefícios que o mesmo pode trazer para o Parque Nacional de Brasília. Pequenos cursos e palestras já podem ser considerados um começo na longa caminhada da conscientização da população do Distrito Federal, que notoriamente já se preocupa mais com a questão ambiental do que a anos atrás, 
devido a grande repercussão que os problemas ambientais encontram na mídia atual. Com atos que muitas vezes passam despercebidos, como por exemplo uma conversa informal, é possível trabalhar a noção ambiental dos visitantes do parque, transformando-os em multiplicadores deste conhecimento.

A Educação Ambiental desperta a cidadania da população, mostrando para estas pessoas que elas estão incluídas dentro de um processo no qual representam um papel importantíssimo, onde não possuem apenas direitos, mas também deveres, dentre os quais está o de zelar pelo patrimônio comum. Essa noção de cidadania que a Educação Ambiental desperta, trás consigo a cobrança das autoridades por parte da população, que se sentindo inserida nesse processo de preservação, possui a necessidade de participar das decisões e de cobrar as melhorias necessárias para a Unidade de Conservação, sendo os principais fiscais dos serviços realizados.

Podemos ressaltar diversos benefícios da inclusão da população no manejo de áreas protegidas, benefícios que não se resumem a economia de recursos financeiros. Além de exercitar a cidadania de pessoas que diversas vezes são consideradas socialmente excluídas, essa inclusão gera o aumento da consciência ambiental da população, principalmente dos voluntários, que passam a compreender a gestão de uma área protegida e as suas dificuldades.

Percebe-se que entre os visitantes do parque encontramos um grande potencial humano, interessado e capaz de trabalhar de alguma forma para auxiliar no manejo da área. Vários dos problemas citados neste trabalho poderiam ser solucionados ou minimizados com o auxilio dessa população. Falta o primeiro passo das autoridades responsáveis para viabilizar e dar início a conscientização e ao treinamento de voluntários na área do Parque Nacional de Brasília, processo que, como vimos neste trabalho, trás benefícios para ambos os lados. 


\section{Referências Bibliográficas}

ABDALA, Guilherme Cardoso. Uma Abordagem Socioecológica do Parque Nacional de Brasília - Estudo de Caso. Brasília: UNESCO, 2002.

DIAS, Genebaldo Freire. Educação Ambiental: princípios e práticas. São Paulo: Global, 1994.

Fundamentos de Educação Ambiental. 2 ed. Brasília: Editora Universa, 2004.

DRUMMOND, José Augusto; FRANCO, José Luiz de Andrade; NINIS, Alessandra Bortoni. O Estado das Áreas Protegidas do Brasil - 2005. Brasília, agosto de 2006. Disponível em: 〈http://www.unbcds.pro.br/conteudo arquivo/150607 2F62A6.pdf. >. Acesso em 29 de agosto de 2009.

GIL, Antonio Carlos. Como elaborar projetos de pesquisa. $4^{\circ}$ ed. São Paulo: Atlas, 2002

FUNATURA - Fundação pró-Natureza; IBAMA - Instituto Brasileiro de meio Ambiente e dos Recursos Naturais Renováveis. Plano de Manejo do Parque Nacional de Brasília. 1998.

MARCONDES, Ayrton César; SOARES, Paulo de A. Toledo. Curso básico de educação Ambiental. São Paulo, Editora Scipioneltda, 1991.

MEDINA, Naná Mininni. Educação Ambiental: Conceitos, Fundamentos e princípios. In: IBAMA. Amazônia - Uma proposta Interdisciplinar de Educação Ambiental. Brasília, 1994.

BRASIL. Decreto no 241, de 29 de novembro de 1961. Cria o Parque Nacional de Brasília, no Distrito Federal, e dá outras providências. Disponível em:

<http://www.ibama.gov.br/cgeam/index.php?id menu=73>. Acesso em 28 de mar. 2009.

Lei ${ }^{\circ}$ 9.795, de 27 de abril de 1999. Dispõe sobre a educação ambiental, institui a Política Nacional de Educação Ambiental e dá outras providências. Disponível em: <http://www.planalto.gov.br/ccivil 03/LEIS/L9795.htm>. Acesso em: 12 de ago. 2009.

Ministério do Meio Ambiente. SNUC: Sistema Nacional de Unidades de Conservação da Natureza: Lei No. 9.985, de 18 de julho de 2000. Brasília: MMA/SBF, 2000. $32 \mathrm{p}$. 
PÁDUA, Suzana Machado. A educação ambiental em áreas de preservação. In: FORUM AMBIENTAL DE MARINGÁ, 2., 2002. Disponível em:

$<$ http://www.maringa.pr.gov.br/forumambiental/anais/educacao_ambiental.htm. $>$. Acesso em 26 de agosto de 2009.

REIGOTA, Marcos. Fundamentos Teóricos para a Realização da Educação Ambiental Popular. Em Aberto, Brasília, v. 10, n.49, p. 35-40, jan./mar. 1991.

.O que é educação ambiental. São Paulo. Brasiliense, 1998.

SALGADO, Gustavo Souto Maior; NOGUEIRA, Jorge Madeira. Economia e Gestão de Áreas Protegidas: O Caso do Parque Nacional de Brasília. In: IV Encontro Nacional da Sociedade Brasileira de Economia Ecológica - ECOECO, 2001, Belém, 2002.

SANTOS, Milton. A Questão do Meio Ambiente: desafios para a construção de uma perspectiva transdisciplinar. In: Revista de Gestão Integrada em Saúde do Trabalho e Meio Ambiente, 2006. Disponível em:

$<$ http://www.interfacehs.sp.senac.br/br/traducoes.asp?ed=1\&cod_artigo=12>. Acesso em 12 de ago. de 2009.

SATO, Michèle. Educação ambiental. São Carlos: EdUFSCar, 1996

TROPPMAIR, Helmut. Biogeografia e Meio Ambiente. 6ed. Rio Claro: Divisa, 2004.

VIEIRA, Paulo Freire et al. Meio ambiente, desenvolvimento e cidadania: desafios para as ciências sociais. São Paulo, Cortez Editora, 1998. 
APÊNDICE

PDF created with pdfFactory Pro trial version www.pdffactory.com 
Universidade de Brasília - UnB

Departamento de Geografia - GEA

Disciplina: Prática e Pesquisa de Campo 2

Aluna: Camila Almeida

$05 / 16571$

\section{Pesquisa sobre a Relação da População e o Parque Nacional de Brasília}

\section{Dados Demográficos:}

1.Faixa Etária:

( ) até 25 anos

( ) entre 46 e 60 anos

( ) entre 26 e 35 anos

( ) entre 36 e 45 anos

2.Sexo:

( ) Feminino ( ) Masculino

3. Escolaridade:

( ) Ensino Fundamental Incompleto

( ) Ensino Superior Incompleto

( ) Ensino Fundamental

( )Ensino Superior Completo

( ) Ensino Médio Incompleto

( ) Ensino Médio

4. Profissão:

\section{Questionário:}

1.Conhece algum outro nome do Parque da Água Mineral ?

( ) não ( ) sim Qual?

2. Com que freqüência visita o Parque?

( ) quase nunca ( ) as vezes ( ) sempre

3. O que já visitou no Parque? (se necessário, marcar mais de uma alternativa)

( ) piscinas ( ) trilhas ( ) Centro de Visitantes

( )Outros:

4. Já ouviu ou leu alguma notícia sobre o Parque?

( ) nunca ( ) raramente ( ) as vezes ( ) frequentemente 
5. Na sua opinião, qual a importância do Parque Nacional de Brasília?

6. Sabe de algum problema enfrentado pelo Parque?
( ) não
( ) $\operatorname{sim}$

Qual?

7. Já recebeu alguma orientação sobre a importância do Parque e como ajudar na sua preservação?
( ) Não
( ) Sim.Onde?

8. Teria tempo disponível ou interesse em auxiliar na preservação do Parque?

( ) não, não tenho tempo disponível ou interesse

( ) Sim, tenho interesse, mas não tenho tempo disponível

( ) Sim, tenho interesse e tempo disponível

9. Como você acha que poderia contribuir com o Parque?

10. Sabe qual a relação entre o Parque e a Barragem de Santa Maria?
( ) não
( ) $\operatorname{sim}$

Qual? 
PDF created with pdfFactory Pro trial version www.pdffactory.com 